\title{
Hillslope-scale experiment demonstrates the role of convergence during two-step saturation
}

\author{
A. I. Gevaert ${ }^{1,2, *}$, A. J. Teuling ${ }^{1}$, R. Uijlenhoet ${ }^{1}$, S. B. DeLong ${ }^{2, * *}$, T. E. Huxman ${ }^{2,3}$, L. A. Pangle ${ }^{2}$, D. D. Breshears ${ }^{2,4}$, \\ J. Chorover ${ }^{2,5}$, J. D. Pelletier ${ }^{2,6}$, S. R. Saleska ${ }^{2,7}$, X. Zeng ${ }^{2,8}$, and P. A. Troch ${ }^{2,9}$ \\ ${ }^{1}$ Hydrology and Quantitative Water Management Group, Wageningen University, Wageningen, the Netherlands \\ ${ }^{2}$ Biosphere 2 - College of Science, University of Arizona, Tucson, Arizona, USA \\ ${ }^{3}$ Department of Ecology and Evolutionary Biology, University of California, Irvine, California, USA \\ ${ }^{4}$ School of Natural Resources and the Environment, University of Arizona, Tucson, Arizona, USA \\ ${ }^{5}$ Department of Soil, Water and Environmental Science, University of Arizona, Tucson, Arizona, USA \\ ${ }^{6}$ Department of Geosciences, University of Arizona, Tucson, Arizona, USA \\ ${ }^{7}$ Department of Ecology and Evolutionary Biology, University of Arizona, Tucson, Arizona, USA \\ ${ }^{8}$ Department of Atmospheric Sciences, University of Arizona, Tucson, Arizona, USA \\ ${ }^{9}$ Department of Hydrology and Water Resources, University of Arizona, Tucson, Arizona, USA \\ * now at: Department of Earth Sciences, VU University, Amsterdam, the Netherlands \\ ** now at: US Geological Survey, Menlo Park, California, USA
}

Correspondence to: A. I. Gevaert (a.i.gevaert@vu.nl)

Received: 30 December 2013 - Published in Hydrol. Earth Syst. Sci. Discuss.: 20 February 2014

Revised: 19 August 2014 - Accepted: 25 August 2014 - Published: 24 September 2014

\begin{abstract}
Subsurface flow and storage dynamics at hillslope scale are difficult to ascertain, often in part due to a lack of sufficient high-resolution measurements and an incomplete understanding of boundary conditions, soil properties, and other environmental aspects. A continuous and extreme rainfall experiment on an artificial hillslope at Biosphere 2's Landscape Evolution Observatory (LEO) resulted in saturation excess overland flow and gully erosion in the convergent hillslope area. An array of 496 soil moisture sensors revealed a two-step saturation process. First, the downward movement of the wetting front brought soils to a relatively constant but still unsaturated moisture content. Second, soils were brought to saturated conditions from below in response to rising water tables. Convergent areas responded faster than upslope areas, due to contributions from lateral subsurface flow driven by the topography of the bottom boundary, which is comparable to impermeable bedrock in natural environments. This led to the formation of a groundwater ridge in the convergent area, triggering saturation excess runoff generation. This unique experiment demonstrates, at very high spatial and temporal resolution, the role of convergence on subsurface storage and flow dynamics. The results bring
\end{abstract}

into question the representation of saturation excess overland flow in conceptual rainfall-runoff models and land-surface models, since flow is gravity-driven in many of these models and upper layers cannot become saturated from below. The results also provide a baseline to study the role of the coevolution of ecological and hydrological processes in determining landscape water dynamics during future experiments in LEO.

\section{Introduction}

Understanding hillslope runoff response to extreme rainfall events is an important topic in hydrology, key to correct prediction of extreme streamflow, erosion and/or landslides, and important to integrated studies of landscapes where such processes affect vegetation dynamics, biogeochemical cycling and biosphere-atmosphere exchanges. In humid regions, saturation excess is one of the dominant mechanisms of overland flow generation (Dunne, 1978; Ward, 1984). Saturation excess occurs when the amount of incoming water exceeds the soil storage capacity at a certain location. Water can enter 
the soil reservoir through vertical infiltration or lateral subsurface flow (Freeze, 1972; Fiori et al., 2007). The development of saturated areas in catchments is central to the variable source area concept, which states that the bulk of catchment runoff is generated from a relatively small fraction of the total surface area of the system (Dunne and Black, 1970; Freeze, 1974). This source area is generally concentrated around a stream bed and can expand upslope into dry channels and laterally up hillslopes. The source areas expand and contract with the seasons (Dunne and Black, 1970) as well as during and after an intense rainfall event (Dunne et al., 1975; Bernier, 1985).

Many factors can influence the development of variable source areas. Firstly, soil hydraulic characteristics play an important role (Dunne and Black, 1970). For example, studies have shown that the presence of a capillary fringe, the zone of the soil profile above the groundwater table that is saturated at negative pore water pressures (Abdul and Gillham, 1984), is critical in the formation of variable source areas (Abdul and Gillham, 1984; Abdul and Gillham, 1989). Other important factors include antecedent moisture conditions (Beven, 1977; Phi et al., 2013), rainfall characteristics (Dunne and Black, 1970) and catchment geomorphology (Beven and Kirkby, 1979). Analytical studies of the effect of slope shape on saturated areas showed that the convergence of subsurface flow generates more saturated areas than planar or divergent alternatives (O’Loughlin, 1981; Troch et al., 2003). In field studies, however, the lack of a sufficiently dense array of subsurface sensors, unknown variability of soil properties and initial/boundary conditions, and the influence of multiple, competing water loss processes and rainfall input dynamics complicate the study of the role of convergence during saturation excess runoff generation.

A new experimental facility at the University of Arizona provides an opportunity to address some of these limitations, at least in part. Data from the hillslopes at the Landscape Evolution Observatory (LEO) at Biosphere 2 in Arizona provide an opportunity to study hillslope hydrological processes under highly controlled conditions. LEO was designed to improve understanding of the evolution of landscapes by studying the interactions between hydrology, ecology and soil science through years of experimentation (Hopp et al., 2009). The main focus of the research on the artificial hillslopes is not to mimic natural conditions, but to study underlying hydrological processes in great detail and under simplified and/or controlled conditions - features that constrain our ability to generate knowledge in natural hillslope settings (Huxman et al., 2009). In the first years of the project, the hillslope will remain devoid of vegetation to limit the relevant processes, but vegetation will be added once the initial set of experiments is completed. The unique experimental setup permits constant rainfall rates and known initial and boundary conditions at hillslope scale and the dense sensor network in the hillslope offers the potential to observe the hydrological response at a high spatial and temporal resolution.
The first experiment in LEO consisted of a single extreme rainfall event that saturated part of the hillslope and led to unintended gully erosion. Previously, Niu et al. (2014) analyzed the hydrological response of this experiment using a physically based model and found that incipient subsurface heterogeneity at the lower end of the hillslope was important to reconcile model based dynamics with measurements. Here, we analyze sensor data collected within the hillslope, focusing on soil moisture data. In Sect. 2, we will describe the instrumentation of the hillslope and the characteristics of the rainfall event. The results of the data analysis with special attention for the effect of convergence during the formation of saturation excess runoff are presented in Sect. 3. The saturation process, groundwater response, and overland flow generation mechanisms are discussed in Sect. 4. In Sect. 5, we will conclude with a short summary that speaks to specific hydrological phenomena, along with a description of hypotheses to guide future experimentation.

\section{Experimental setup}

Our study focused on the first of three LEO hillslopes at Biosphere 2. The hillslope is $11 \times 30 \mathrm{~m}$, and has an overall slope of $10^{\circ}$. The slope has a convergent shape with a central trough running from the toe of the slope to $18 \mathrm{~m}$ upslope (Fig. 1). The overall slope between the central trough and the far sides of the hillslope is $7^{\circ}$. The upslope, bottom and side boundaries are impermeable. At the toe of the slope a $0.5 \mathrm{~m}$ wide gravel section and a perforated plate followed by an open trough provide seepage face boundary flow conditions. The hillslope has been filled to a constant depth of $1 \mathrm{~m}$ using granular basaltic tephra ground to the texture of loamy sand. During construction of the hillslope, loose material was spread over a cross-slope strip of the hillslope and subsequently compacted to a specified depth. This process was repeated for several vertical layers and horizontal strips of the hillslope moving from the toe of the slope to the upper end. Soil cores from a barrel that was filled and compacted by the same method were used to measure relevant soil characteristics. The cores were taken from the barrel rather than the hillslope itself to limit disturbance of the hillslope. The material has a porosity of 0.39 , a bulk density of $1.59 \mathrm{~g} \mathrm{~cm}^{-3}$ and a capillary fringe of approximately $30 \mathrm{~cm}$. The van Genuchten curve was determined using Tempe cells and a WP4-T Dewpoint Potentiometer for the wet and dry ends, respectively (curve and relevant parameters provided in Fig. 2). The saturated hydraulic conductivity of the material based on column experiments is $1.92 \mathrm{~m} \mathrm{~d}^{-1}\left(2.2 \times 10^{-5} \mathrm{~m} \mathrm{~s}^{-1}\right)$. However, based on the particle size distribution, the saturated hydraulic conductivity is $0.67 \mathrm{~m} \mathrm{~d}^{-1}\left(7.8 \times 10^{-6} \mathrm{~m} \mathrm{~s}^{-1}\right)$, and later model calibration suggested that the effective value at hillslope scale is closer to $12.10 \mathrm{~m} \mathrm{~d}^{-1}\left(1.4 \times 10^{-4} \mathrm{~m} \mathrm{~s}^{-1}\right)$ (Niu et al., 2014). We do not expect that the saturated hydraulic conductivity was significantly anisotropic during this 


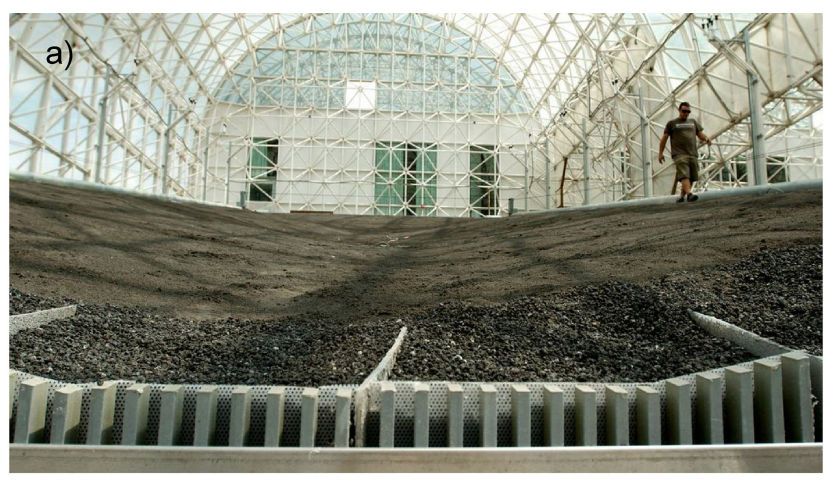

b)
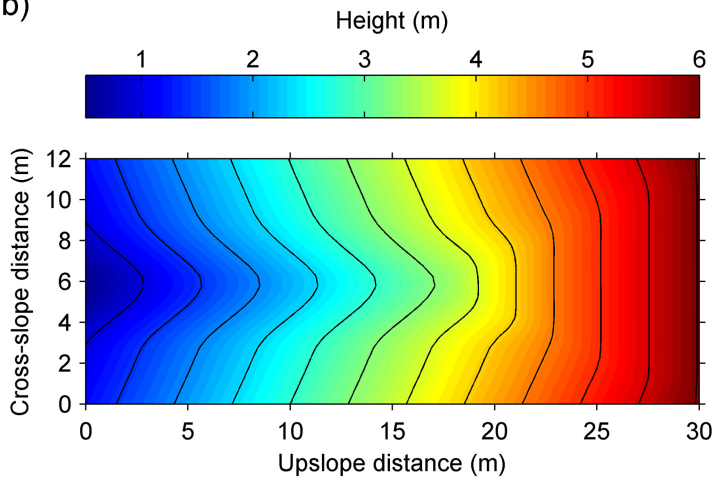

Figure 1. Hillslope design. (a) Photo of one of the Biosphere 2 hillslopes. (b) Topographic map of the hillslope with contours (solid lines) drawn every $0.5 \mathrm{~m}$. Note the convergent trough in the center. The soil has a constant depth of $1 \mathrm{~m}$.

experiment because the material and compaction are homogeneous and this was the first experiment to be performed on the hillslope. In this paper, the hillslope is divided into a convergent and upslope area to study the effect of convergence (Fig. 3).

Subsurface flow is collected along the lower end of the hillslope, which is divided into six sections. From each section, the flow is routed to an electromagnetic flow meter and a tipping bucket, installed in series. A composite of measurements from these instruments gives accurate estimates of flow $\left(R^{2}=0.99\right)$ when compared to known flow rates. Though instrumentation to measure overland flow is absent, estimates were made by two different methods. Before the rainfall was turned off, estimates were based on water balance analysis using measured precipitation, storage and subsurface flow data. The evaporation term was neglected because this period was during the night. After the rainfall was turned off, overland flow was collected every half hour and the flow rate was calculated based on the time that was needed to fill a fixed volume.

Within the hillslope area, an array of 496 5TM Decagon (Pullman, WA, USA) soil moisture sensors recorded volumetric water content (VWC) with an error margin of $\pm 2 \%$. These are located on a regular grid of 154 vertical transects

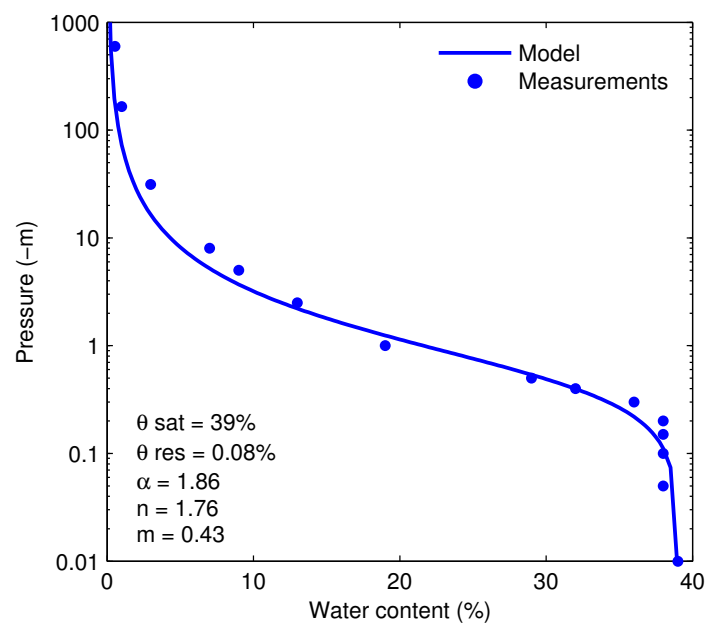

Figure 2. Laboratory measurements of the water retention curve and the van Genuchten model that best fits the measurements. The parameters describing the curve are shown in the plot.

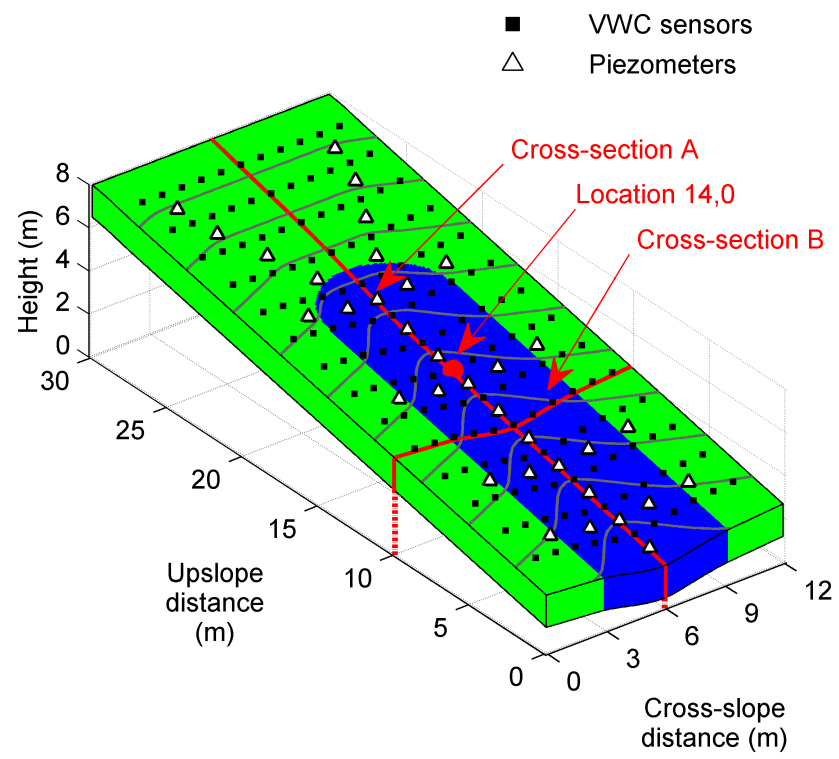

Figure 3. Schematization of the instrumentation of the hillslope with a vertical exaggeration factor of 1.5. The figure shows contour lines (grey), locations of soil moisture sensors, piezometers, and cross-sections used for analysis. The convergent zone of the slope, defined as all locations within $3 \mathrm{~m}$ of the central trough, is shown in blue, and the upslope area in green.

(Fig. 3). At each transect, sensors are located at 3 or 4 depths between 5 and $85 \mathrm{~cm}$ below the soil surface. In addition, the groundwater table is measured by 34 vibrating wire piezometers (GeoInstruments, San Francisco, CA, USA) installed at the bottom of the soil profile. These are placed along the central trough and along several cross-sections of the hillslope (Fig. 3). Also, ten load cells measure the total system mass, which can detect mass change equivalent to less than $1 \mathrm{~cm}$ of water $( \pm 0.05 \%)$. 
Rainfall was applied to the hillslope by means of a sprinkler network, and was measured by an electromagnetic flow meter in the irrigation line. The experiment consisted of a single continuous rainfall event with a constant intensity of $12 \mathrm{~mm} \mathrm{~h}^{-1}$. This experiment was intended to bring the hillslope to hydrologic steady state rather than to be in line with a specific climate, and the rainfall rate was chosen due to its relatively even spatial distribution. However, after $22 \mathrm{~h}$, overland flow and erosion were observed and rainfall was stopped to prevent further unplanned changes to the topography of the hillslope. The total rainfall depth of the resulting event is similar to events that can trigger discharge extremes and/or landslides in natural environments (Turner et al., 2010; Brauer et al., 2011; Nguyen et al., 2013). Initial conditions were relatively dry, with volumetric water content of $8-11 \%$ in most of the hillslope, except for the bottom of soil near the central trough where conditions were wetter due to rainfall system delivery testing several weeks prior to the current experiment (Fig. 4a). Data were collected from all instruments every $15 \mathrm{~min}$.

\section{Results}

The rainfall event unexpectedly saturated part of the hillslope to the surface in and close to the central trough. Soil moisture time series show that the saturation process can be described by a sequential step-wise process rather than by a gradual process at all depths: three relatively stable phases (1-3) were separated by two rather abrupt steps. These steps are visible at individual locations (see examples in Fig. 5a) as well as in horizontally averaged data over the whole hillslope, over the convergent area only, and over upslope area only (example for $35 \mathrm{~cm}$ depth in Fig. S1 in the Supplement).

The time series in Fig. 5a as well as the time series of all other sensors that reached saturated conditions during the experiment show volumetric water contents exceeding the maximum porosity determined in the laboratory. The sensors were calibrated before they were installed in the hillslope by exposing the sensors to typical soil moisture values in the same soil material. The overshoot was not observed during this process. Soil moisture values closer to saturation were included in a second calibration after the experiment, but again no overshoot was observed and there were no significant changes in the calibration curves. Further testing of soil moisture sensors in large barrels under control conditions showed that the sensors read values exceeding the porosity of the soil when influenced by a capillary fringe or groundwater table. However, the relation between the overshoot and the depth under the groundwater table was not clear. Therefore, saturation is assumed when measured volumetric water contents exceed the porosity determined in the laboratory. This assumption is further justified by comparing storage estimates based on spatial averaging of soil moisture data and load cell measurements. Spatial averaging of raw soil
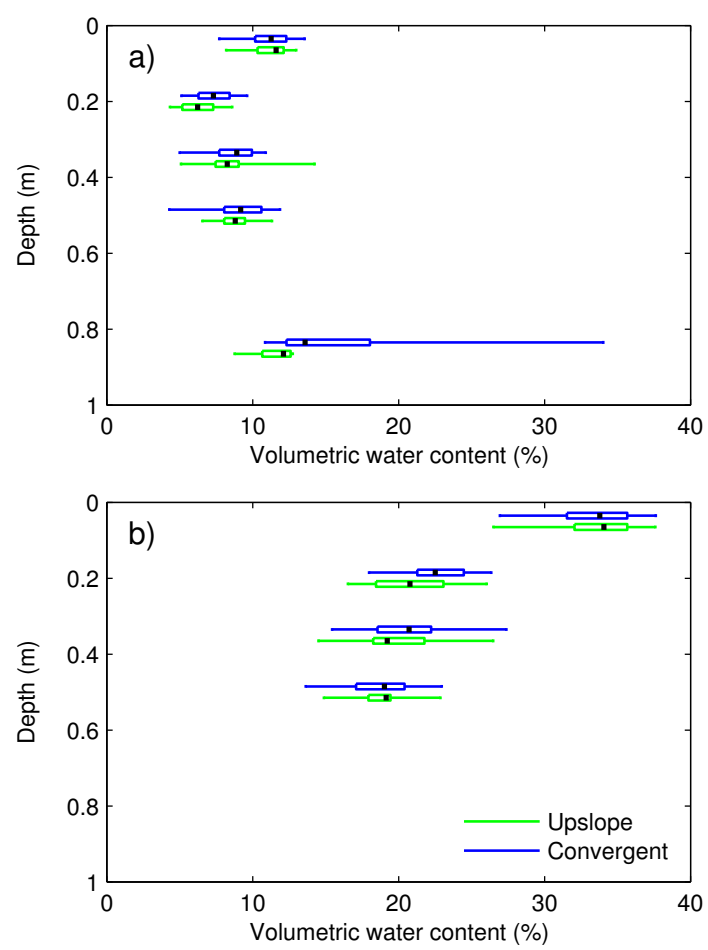

Figure 4. Box-and-whisker plots show the volumetric water content in phase 1 (a) and phase 2 (b) for the convergent and upslope areas and for each sensor depth. The whiskers show the 5th and 95th percentiles. Sensor depths are slightly offset to improve the visibility of the data.

moisture data resulted in significant overestimation of storage compared to the change in system mass measured by the load cells. This estimate was also significantly larger than the cumulative rainfall. When a maximum moisture content of $39 \%$ was used, however, estimates compared well to load cell data (Fig. 5b).

Unfortunately, the piezometer data showed sensitivity to ambient temperature fluctuations. Due to this, piezometers read both negative values as well as values exceeding the soil depth of the hillslope (Fig. 6). Under normal applications these piezometers hang in deep wells where temperatures are more or less constant. In our application, the piezometers are mounted on the bottom of the hillslope and are subject to diurnal temperature fluctuations. It was impossible to find a reliable correction method, so values are reported relative to the initial conditions, when there was no groundwater table. While the values should not be interpreted as accurate representations of actual groundwater levels, the data nonetheless do provide a qualitative assessment of groundwater table dynamics.

The first step in the saturation process marked a sudden increase from initially dry conditions in the first phase to wetter, but still unsaturated conditions in the second phase (Fig. 5a) corresponding to the arrival of the infiltration front. After the passage of the infiltration front, the soil moisture 

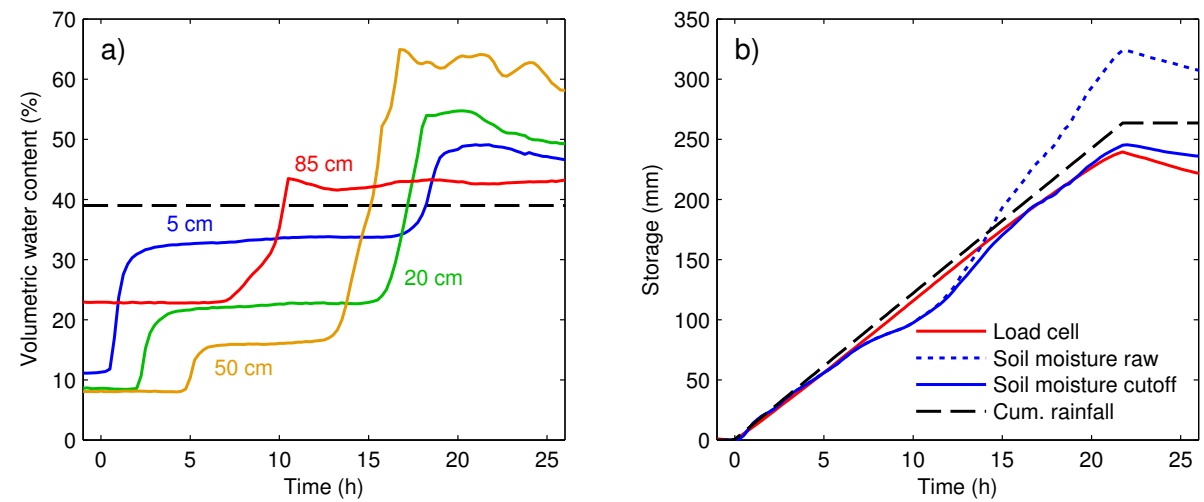

Figure 5. Volumetric water content (a) and storage estimates (b) in time relative to the start of the rainfall event. The volumetric water content is shown for four sensors along a vertical transect at a location $(14,0)$, where depths are relative to the surface. A horizontal line indicates the maximum porosity, above which locations are considered to be saturated. Storage estimates (b) relative to initial storage are derived from (i) load cell data, (ii) spatial averaging of raw soil moisture data and (iii) spatial averaging of soil moisture data with a cutoff of $39 \%$. Cumulative rainfall is added to the plot as a reference.
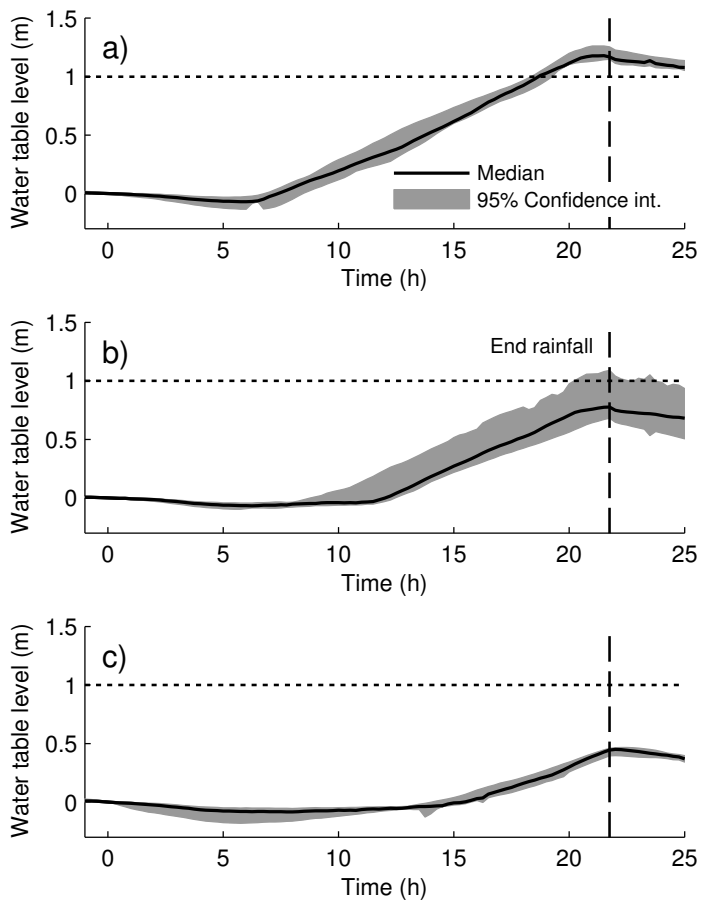

Figure 6. Median groundwater levels and the $95 \%$ bootstrap confidence intervals are shown for piezometers in the central trough (a), convergent area (b) and upslope area (c). Plotted water table levels are relative to initial conditions, when no groundwater table was present. The dashed line marks the end of the rainfall event and the dotted line represents the soil surface.

content stayed steady in time but decreased with depth (Figs. 5a and 4b). The mean and median moisture contents at each depth in phase 2 were significantly different $(p<0.01)$. The second step marked a transition from unsaturated but wet conditions in the second phase to saturated conditions in the third phase, marking the arrival of the saturation front. Sensors at $85 \mathrm{~cm}$ depth behave differently, and show a single step from phase 1 (initial conditions) directly to phase 3 (saturated conditions).

Phase 2 was observed first at the shallower sensors hours after the start of the rainfall event $(T=5.5 \mathrm{~h})$, and propagated downwards to the bottom of the soil profile (crosssections A and B in Fig. 7). The third phase was observed first at the lower sensor depths and moved to the surface. Although the propagation of the second phase was relatively even across the hillslope, that of the third phase was not. The third phase reached the soil surface in and near the central trough $(T=16.5-22 \mathrm{~h})$, while at the far sides and top of the hillslope it did not reach above $50 \mathrm{~cm}$ depth. The difference in expansion in the convergent and upslope areas formed a groundwater ridge in the cross-slope direction. The groundwater ridge was observed in both soil moisture data (Fig. 7b) and piezometer data (Fig. 8). The development of the three saturation phases at hillslope scale is shown in Animation S1.

The difference in the level of saturation in the convergent and upslope areas was further analyzed by means of simple column storage calculations. A maximum value equal to the porosity was applied to the data to prevent the observed overshoot in soil moisture values (Fig. 5a) from influencing the calculations. The results of the calculations show that soil columns in the convergent area saturated sooner than would be expected based on the rainfall rate and initial soil moisture conditions alone. In the central trough, the difference was equivalent to $3-4 \mathrm{~h}$ of rainfall. On the other hand, storage in upslope areas was less than would be expected. This indicates that there was an additional net incoming flux in the convergent area and a net outgoing flux in the upslope area.

Subsurface flow at the bottom of the hillslope started after $13 \mathrm{~h}$ of rainfall. Overland flow measurements are uncertain, but started after $14-20 \mathrm{~h}$ and continued until approximately 
a)

Cross-section A

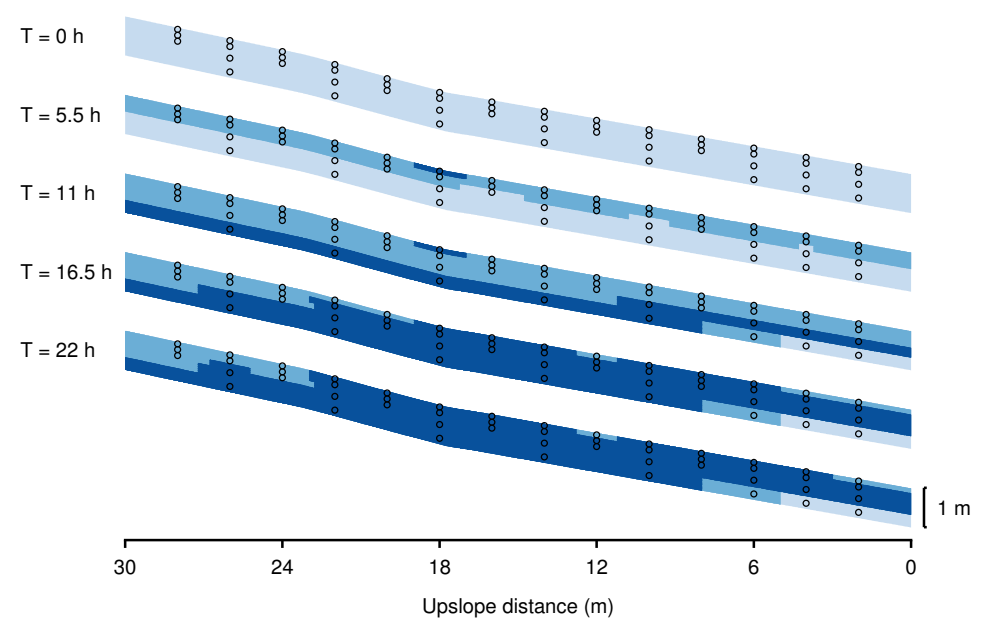

b)

Cross-section B

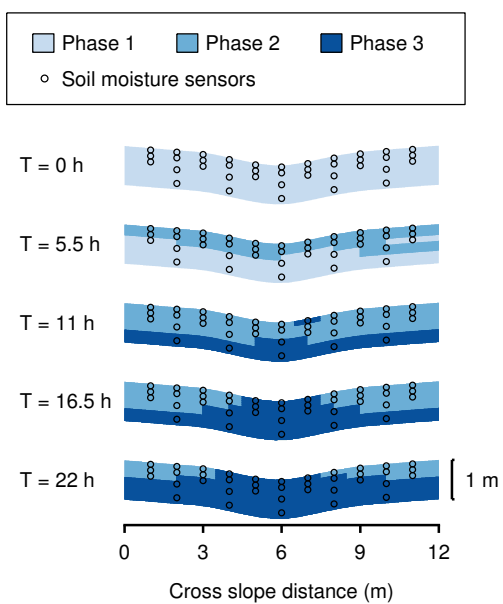

Figure 7. The development of the two-step saturation between the start $(T=0 \mathrm{~h})$ and end $(T=22 \mathrm{~h})$ of the rainfall event for crosssections A (a) and B (b). Open circles show soil moisture sensor locations.
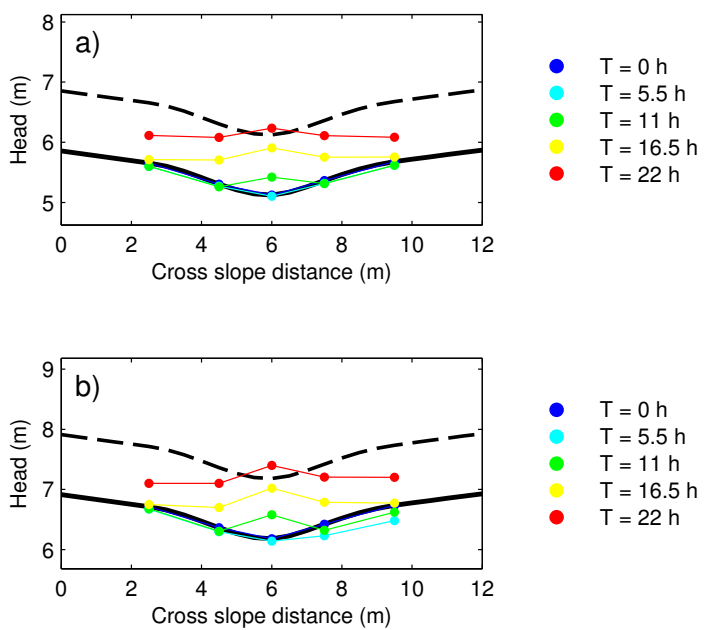

Figure 8. Piezometric data for two cross-slope transects at 7 (a) and $13 \mathrm{~m} \mathrm{(b)} \mathrm{from} \mathrm{the} \mathrm{toe} \mathrm{of} \mathrm{the} \mathrm{slope} \mathrm{are} \mathrm{shown} \mathrm{at} \mathrm{several} \mathrm{time}$ steps between the start and end of the rainfall event. The solid line represents the impermeable boundary at the bottom of the hillslope and the dashed line represents the soil surface.

$24 \mathrm{~h}$ after the rainfall was turned off (Fig. 9a). According to soil moisture data, saturation first reached the surface after 18-19h (Fig. 9b). Once the groundwater ridge reached the surface, it expanded along the side slopes of the central trough. The ridge created a slightly reversed hydraulic gradient from the ridge in the direction of the side slopes. This gradient was strongest when the ridge had just reached the surface and then slightly decreased in time (Fig. 7). Longitudinal cross-sections shown in Fig. 7a reveal increasing saturation in the downslope direction along the upper part of the hillslope. Saturation at the surface occurred along the lowest $20 \mathrm{~m}$.

The hillslope is divided into a convergent and upslope part to compare the timing and speed of the saturation and subsequent drying processes. The timing of step 1 is the time at which the soil moisture starts to increase and marks the transition from phase 1 into phase 2 . In the same way, the timing of step 2 marks the transition from phase 2 to phase 3 . The relationship between sensor depth and the timing of step 1 was approximately linear for both parts (Fig. 9b). The speed of the infiltration front based on this relationship was $7.8 \mathrm{~cm} \mathrm{~h}^{-1}$ in the convergent area and $6.7 \mathrm{~cm} \mathrm{~h}^{-1}$ in the upslope area. However, the difference in timing was not significant based on the bootstrap confidence interval $(p=0.15)$.

Once the infiltration front reached the bottom of the soil profile, a water column quickly formed and rose upwards (Fig. 9b). In contrast to the infiltration front, the development of saturation in the soil profile was significantly different between the two areas. First, at each soil depth step 2 was observed significantly sooner in the convergent area than in the upslope area. In addition, step 2 was not observed near the surface in the upslope area, meaning that these areas did not reach phase 3 . This is supported by the piezometer data, where groundwater table levels reached the surface in the central trough but stayed lower in the upslope area (Fig. 6). However, the speed of the propagation of step 2 was similar in the convergent and upslope areas, at 15.5 and $15.0 \mathrm{~cm} \mathrm{~h}^{-1}$, respectively, or about two times faster than the infiltration front. The uncertainty in groundwater level values prevents us from accurately estimating the speed of groundwater table rise.

The difference between the convergent and upslope areas was also evident during the subsequent drying phase. The 
a)

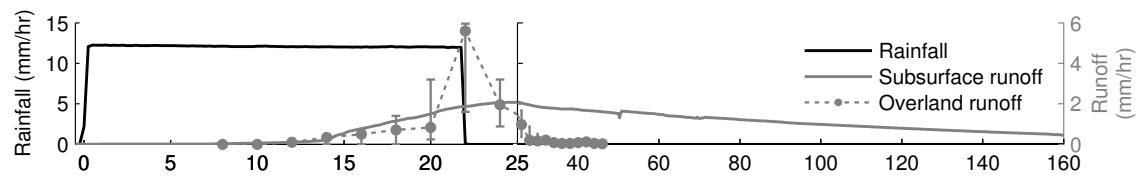

b)

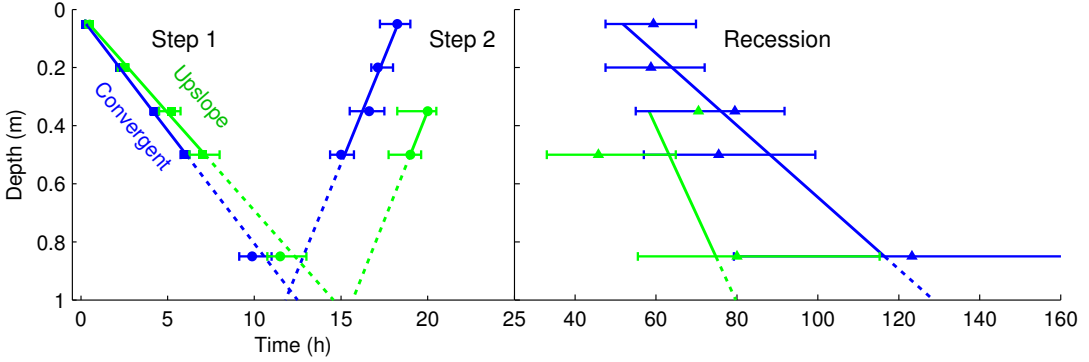

Figure 9. The rainfall-runoff characteristic (a) and the timing of different phases of saturation and recession for the convergent and upslope areas (b). Time is relative to the start of the rainfall event and depth is relative to the soil surface. Overland flow estimates (a) are based on water balance analysis and volumetric measurements, and error bars express operator's uncertainty. In (b), the median timing of each phase is shown with error bars representing the $95 \%$ bootstrapping confidence interval of the median. Lines show best fits through the medians and are solid within the range of fitting and dotted when extrapolated.

recession start time is defined as the time at which the soil moisture in a saturated location first drops below the maximum porosity. This phase was slower than the wetting phase and started in relatively shallow or upslope locations before moving on to deeper locations and the convergent area (Fig. 9b). Subsurface flow at the toe of the slope peaked just after the end of the rainfall event and had a long recession tail (Fig. 9a). Overland flow peaked at the time rainfall was turned off, though the size of this peak is very uncertain. Runoff over the surface then continued for more than $24 \mathrm{~h}$ after the sprinklers were turned off, causing erosion in the central trough. This erosion formed a gully extending $18 \mathrm{~m}$ upslope, and changed the topography of the hillslope.

\section{Discussion}

Our results increase understanding of the behavior of saturation excess overland flow, and thereby can contribute to the development of how robust hydrological models and Earth system processes are impacted by surface and subsurface flow behavior. LEO represents an opportunity to experimentally approach these issues to refine models and then connect the processes to real settings. It is important to note that LEO's experimental setup is more typical of a zeroorder basin than a hillslope due to the impermeable lateral boundaries of the artificial hillslope. Nonetheless, we expect that this system would behave similarly without these boundaries, and results of this experiment should be relevant for both. Rainfall falling on any part of the hillslope is eventually routed towards the central trough due to the convergent topography of the hillslope (Fig. 3). The topography of the bottom impermeable boundary or bedrock rather than the surface is the main driver of this convergent flow. Due to the convergence, flow over the lateral boundaries would only be relevant once the groundwater table extends to the sides of the hillslope. In natural hillslopes, water would then move across those boundaries to adjacent hillslopes. However, in natural rain events, adjacent hillslopes will receive similar amounts of rainfall and thus the groundwater table may rise in a similar fashion, sustaining the no-flow boundary at the topographic divide. Our results provide insights related to a two-step saturation, groundwater ridging, and overland flow.

\subsection{Two-step saturation}

The results show that the hillslope is saturated by a stepwise process, as has been previously observed in small-scale experiments on slopes with planar geometry (Phi et al., 2013). Identification of the steps and phases is aided by the experimental setup with constant rainfall rates, but is likely more challenging in natural catchments due to the rare nature of intense storms and the fact that soil moisture signals will also reflect the effect of varying rain rates. The steps were not only visible at individual locations (example in Fig. 5a), but also in aggregated data to the scale of the convergent area, upslope area and the entire hillslope (Fig. S1 in the Supplement). This demonstrates that the two-step process is relevant to both fundamental hydrological understanding and land surface modeling in weather, climate, and hydrological simulations that treat heterogeneous surfaces (such as the whole area in LEO) as a single grid box.

In our hillslope-scale experiment, the steps are very consistent throughout the hillslope, apart from a few individual locations that seem to show different behavior. One of these is at the bottom of the soil profile at the toe of the slope, where sensors appear to stay in phases 1 and 2 and therefore do not reach saturation (Fig. 7). However, the soil moisture content in these locations reaches over $36-37 \%$. Taking the $\pm 2 \%$ error margin of the sensors into account, the moisture 
content comes quite close to the maximum porosity, and we expect that these locations were likely saturated.

Another local deviation is observed in the slightly asymmetrical infiltration front (Fig. 7), which would not be expected in a homogeneous soil. However, at hillslope scale, there is very little scatter around the linear relationship between timing of the first step and sensor depth (Fig. 9). This suggests that the first observation is due to small-scale variations resulting from the indicated time and location of the cross-section, while at hillslope scale the soil is relatively homogeneous compared to natural hillslopes. Although the scale of the hillslope prevents truly homogeneous conditions, the absence of vegetation and other disturbances excludes the formation of instabilities, which can have a large influence on flow paths, such as finger flow or macropore flow (e.g., Beven and Germann, 2013). Soil cracks can form due to swelling and shrinking as minerals absorb and release water, but this is unlikely in LEO because the soil does not contain the clay minerals required for this process. However, in the future, we expect that the subsurface structure of the hillslope will constantly change as more experiments are executed and hydrological pathways develop, especially after vegetation is introduced.

The two-step saturation process supports existing theories of water movement in hillslopes in which water first moves vertically through the unsaturated zone, contributes to the formation of a groundwater table, and subsequently moves downslope. This concept is an important assumption in previous physically based modeling studies (e.g., Robinson and Sivapalan, 1996). In fact, due to the dense sensor network and highly controlled conditions, LEO is well suited to testing assumptions and concepts in hydrological models.

Conceptual models can simulate two-step saturation by including a tension water reservoir and a free water reservoir, as in the Sacramento model (Burnash et al., 1973; Duan et al., 2001) and the Xinanjiang model (Zhao, 1992). In these models, water infiltrates into the tension reservoir, which represents available soil water. Once the tension reservoir has been filled, water is routed to the free water reservoir. The free water reservoir represents gravitational soil water and is therefore likely to fill from the bottom upwards as was observed in this experiment. Another important characteristic of the saturation process is the role of convergence. In this experiment, the difference in timing and degree of saturation as well as the timing of the recession period indicate there was flow from the upslope area to the convergent area forced by the topography of the bedrock. The results of column storage calculations also support the importance of lateral subsurface flow. However, these and other conceptual models only allow for one-way interaction between reservoirs, and do not allow for lateral redistribution of water (e.g., Duan et al., 2001; van Esse et al., 2013; Zhao, 1992), which was a crucial mechanism of overland flow generation in this experiment, due to the relatively shallow soil.
Field studies on saturation and overland flow generation have shown similar development of saturated areas (Dunne and Black, 1970; Wilson and Dietrich, 1987) as observed in phase 3 of the saturation process. One study focusing on the role of topography in throughflow generation on a hillslope with similar characteristics to the artificial hillslope in this study also suggested the importance of convergent soil water flow in the formation of the saturated wedge (Anderson and Burt, 1978). However, the resolution of data collected during field studies is often limited (Anderson and Burt, 1978; Dunne and Black, 1970), and results are affected by environmental factors such as varying rainfall rates (Anderson and Burt, 1978) or bedrock permeability (Wilson and Dietrich, 1987). The present study of the saturation process uniquely combines high-resolution data and controlled conditions with near-field scales.

Although the main concept of the two-step saturation process is in line with existing theories in hillslope hydrology, some observations are not easily explained. In the case of a constant infiltration rate and a homogeneous soil, one would expect the equilibrium moisture content of phase 2 to be similar at all depths based on Richards' equation. Instead, our data show a significant decrease in soil moisture content with depth in the second phase in both convergent and upslope areas at hillslope scale (Fig. 4b). Air entrapment is a possible explanation for this observation, but is not deemed likely for a few reasons. First, air entrapment is observed when there is ponding at the surface (Culligan et al., 2000; Starr et al., 1978), for example during surface irrigation (Dixon and Linden, 1972). During this experiment, we did not observe ponding on the surface during the second phase. Furthermore, we observe the decrease in moisture content at times when none of the overlying soil is saturated, leaving enough empty pores for pressurized air to escape. Finally, the rainfall intensity distribution was not completely uniform over the hillslope and the scale of the hillslope makes air entrapment unlikely. A second possible explanation for the decreasing water content, yet constant specific infiltration rate, is decreasing porosity with depth. However, if we assume a significant decrease in maximum porosity, storage estimates by spatial averaging of soil moisture data significantly underestimate storage estimates based on load cell data shown in Fig. 5b. Another possibility is that there are changes in water retention characteristics with depth. In the relevant part of the retention curve, small changes in soil water pressure can lead to relatively large differences in soil moisture content. Finally, an increasing hydraulic conductivity with depth could also explain the observations, though this is deemed unlikely to develop from an initially homogeneous soil profile. The true explanation for these observations cannot be determined based on the collected data, and requires further research into the role of vertical heterogeneity in soil hydraulic properties. A hypothesis that can be tested after the introduction of vegetation in LEO to learn more about this phenomenon is that the presence of roots will reduce soil moisture values 
at shallower soil depths due to increased potential for preferential flow.

Other interesting observations concern the speeds of the downward propagating infiltration front and the upward propagating saturation front. The infiltration front speed as reported in the Results section $\left(6-7 \mathrm{~cm} \mathrm{~h}^{-1}\right)$ is more than five times faster than the applied rainfall rate $\left(1.2 \mathrm{~cm} \mathrm{~h}^{-1}\right)$. The fact that the moisture content is relatively stable in time after the passage of the wetting front suggests that the specific flux is constant with depth. At the same time, this flux must be equal to the rainfall rate at the surface. This suggests that a limited portion of the available pore space in the soil is used in water transport. The saturation front speed is higher than the infiltration front speed, which can be linked to the smaller specific yield between the second and third phases than between the first and second phases. We would expect the rise of the saturation front to accelerate due to decreasing available pore space (Fig. 4b), but we do not observe this at hillslope scale. Decreasing porosity with depth could explain this observation. However, as mentioned previously, this would result in an underestimation of system storage, and is therefore unlikely. Finally, we would expect the speed of the saturation front to be higher in the convergent zone than in the upslope area in the presence of flow convergence. Instead, the speeds in both areas are very similar (Fig. 9b). On the other hand, the error bars do not exclude the possibility of accelerated groundwater table rise or faster groundwater table rise in the convergent area than the upslope area. Furthermore, the number of locations that reach phase 3 at $35 \mathrm{~cm}$ depth in the upslope area is limited, reducing the power of the observed rate of groundwater table rise in the upslope area.

\subsection{Groundwater ridging}

Piezometer data (Fig. 8) indicate that a groundwater ridge formed during the rainfall event. Though soil moisture data indicate saturation rather than the phreatic surface, the soil moisture data support the piezometer data due to the similarity in ridge development in both data sets (Fig. 7b). The piezometer and soil moisture data are not co-located, but the level of the ridge in the soil moisture data appears higher than that in piezometer data. At first glance this could be explained by the capillary fringe. However, it is important to remember that the groundwater table values are not accurate, as shown by the negative values and the values extending above the soil surface (Fig. 6). The reversed hydraulic gradient was highest when the ridge reached the surface and then decreased due to continued rainfall and subsurface flow along the gradient (Cloke et al., 2006).

Several studies have linked the formation of a groundwater ridge to the presence of a capillary fringe (Gillham, 1984; Abdul and Gillham, 1984; Abdul and Gillham, 1989). Theory predicts that when rainfall is added to a soil where the capillary fringe reaches the land surface, the groundwater table rises rapidly and a groundwater ridge is formed. How- ever, studies have not clearly demonstrated this mechanism in practice. In studies by Gillham (1984) and Novakowski et al. (1988), groundwater tables did not rise to the surface in response to rainfall events even though the capillary fringe extended to the surface. Another study in Canada described the development of a groundwater mound in response to infiltrating snowmelt, but observed gradual rather than rapid groundwater table rise (Buttle and Sami, 1992). In addition to the height of the capillary fringe, studies have identified several other factors that influence groundwater ridging. Waswa et al. (2013) found that the magnitude of the groundwater ridging response was linearly related to the maximum rainfall intensity of an event. A numerical study by Cloke et al. (2006) also showed that rainfall intensity influenced the development of a groundwater ridge, but found other factors such as the slope, saturated hydraulic conductivity and initial water table height to be more important.

In many studies of groundwater ridging, initial groundwater tables were (nearly) horizontal (Abdul and Gillham, 1984; Novakowski et al., 1988; Abdul and Gillham, 1989; Buttle and Sami, 1992). As a consequence, the distance to the groundwater table was lower near the stream than farther upslope and the capillary fringe often reached the surface for only a limited difference from the stream. Linked to this, the specific yield was lower near the stream than upslope. Under these conditions, areas near the stream respond quickly to rainfall, while upslope areas respond more slowly, allowing a groundwater ridge to form. In the present study, there was no initial groundwater table and the soil depth is uniform, limiting the influence of the capillary fringe in groundwater ridge development. The specific yield was not completely uniform in the hillslope due to differences in initial conditions of the lowest soil layer (Fig. 4). However, the column storage calculations indicate that there was net flow from the upslope area to the convergent area despite the reversed hydraulic gradient. This suggests that the formation of the groundwater ridge in this study is affected by subsurface flow driven by the convergent topography of the bedrock.

\subsection{Overland flow}

The estimation of overland flow based on the water balance indicates that overland flow may have started as early as $14 \mathrm{~h}$ after the start of the rainfall event (Fig. 9). Overland flow starting before saturation reached the surface would suggest Hortonian overland flow rather than Dunnian overland flow. However, the error bars extend to zero until $20 \mathrm{~h}$ into the event due to uncertainties in the water balance analysis, and we do not expect Hortonian flow to have occurred for several reasons. First, the constant rain rate is lower than the saturated hydraulic conductivity, both as determined in the laboratory as determined by model calibration. Second, overland flow was not observed for the first eight hours of the experiment and once overland flow started it was limited to the central trough. Third, in subsequent experiments with the same 
rainfall rate, but a shorter duration, no ponding or overland flow was observed. Finally, model simulations based on the 3-D Richards equation do not show overland flow due to infiltration excess, but confirm overland flow due to saturation excess in the central trough (Niu et al., 2014).

A possible explanation for the overland flow is that tension saturation at the surface caused saturation excess runoff to occur. However, the continuation of overland flow after rainfall had stopped indicates that lateral subsurface flow was a major contributor to overland flow generation in this experiment. Piezometric data can help justify this interpretation. The data should not be used as accurate portrayals of groundwater levels; however, the data (Fig. 6) support the timing of water table rise (Fig. 9) and suggest that the water table reached the surface in the central trough. The continuation of overland flow for a long period after rainfall had stopped also signals a persistent hydrologic connectivity between upslope and convergent areas. Previously, Sklash and Farvolden (1979) demonstrated that runoff in their study area could be dominated by either event or pre-event water, depending on initial conditions. Under wetter conditions, such as was the case at the onset of runoff in the present study, overland flow and streamflow hydrographs were dominated by groundwater (Sklash and Farvolden, 1979).

Initially, the subsurface component of overland flow in the present experiment was caused by the groundwater ridge alone. However, gully formation and expansion influenced flow paths in the hillslope. The erosion gully formed by the overland flow was limited to the central trough in the hillslope. A study of rill formation in the artificial Chicken Creek catchment showed a larger network of rills, but the longer and deeper main rill was similarly located along the convergent axis of the catchment (Hofer et al., 2012). It is expected that the steep sides of the gully in the present study increased local hydraulic gradients, increasing runoff generation and the related erosion while groundwater levels remained high on either side of the gully. In this way, the subsurface component of overland flow was enhanced by morphologic changes caused by erosion.

\section{Conclusions and outlook}

The Landscape Evolution Observatory at Biosphere 2 consists of a hillslope-scale experiment in a highly controlled setting, where the first rainfall experiment resulted in overland flow and soil erosion. This experiment provided a unique opportunity to study the importance of convergence on the development of saturation through the use of the high-density sensor array in the system. Data collected from 496 soil moisture sensors at a high temporal resolution show a two-step saturation process: a first step related to the downward propagation of the infiltration front and a second step characterized by saturation of the soil from below in response to rising water tables. Soil profiles in convergent areas re- sponded sooner than soil profiles in upslope areas. In addition, soil profiles in the convergent area saturated completely, while the soil surface in the upslope area remained unsaturated. This difference created a groundwater ridge. Due to the uniform soil depth and lack of soil heterogeneity, the difference between the two areas can be attributed solely to lateral subsurface flow in the saturated zone of the soil profiles driven by the convergent topography of the bedrock.

Our experimental data demonstrate the importance of convergence in the context of existing theories describing hillslope hydrology. Convergence influences subsurface flow and storage dynamics at hillslope scale, which alters the timing of the two-step process by location, and the degree of saturation in different topographic positions. Several observations at hillslope scale are not easily explained by existing theory and likely emerge from the large-scale nature of the experiment or the important differences in system complexity associated with the lack of vegetation and spatial heterogeneity. One important question is how to explain the observed decreasing moisture content with depth despite constant infiltration rates and a homogeneous soil. Further research into vertical heterogeneity and small-scale processes is needed to explain the mechanisms behind these observations. Insight in these mechanisms is an important step to improve understanding of saturation excess overland flow generation and related natural hazards such as flash floods and landslides, and their representation in land surface models, many of which currently do not allow for lateral and/or upward movement of water. The results of this experiment also set the stage for hypotheses concerning the role of vegetation in altering wetting dynamics that can be tested in LEO. One such hypothesis is that the resulting macro-pore structure should create more homogeneous changes in water content by facilitating water flow to soil depths. Comparison of the results of this experiment and such future experiments can highlight the role of the co-evolution of ecological and hydrological processes in determining landscape water dynamics.

\section{The Supplement related to this article is available online at doi:10.5194/hess-18-3681-2014-supplement.}

Acknowledgements. We thank all of the technicians and graduate students involved in preparing and performing this experiment. Of these, we are especially grateful to Michael Sibayan, John Adams and Nate Abramson for technical support and Yvonne Smit for providing data on soil properties. We also thank George Waswa, reviewer Erwin Zehe and two anonymous reviewers for their constructive comments, which greatly helped improve the manuscript. In addition, we thank Murugesu Sivapalan, Ciaran Harman and William Dietrich for their thoughts about an earlier version. Finally, we are grateful to Paul Ingram for providing the hillslope photograph. Primary support for LEO is from the Philecology Foundation (Forth Worth, TX, USA).

Edited by: F. Tian 


\section{References}

Abdul, A. S. and Gillham, R. W.: Laboratory studies of the effects of the capillary fringe on streamflow generation, Water Resour. Res., 20, 691-698, 1984.

Abdul, A. S. and Gillham, R. W.: Field studies of the effects of the capillary fringe on streamflow generation, J. Hydrol., 112, 1-18, 1989.

Anderson, M. G. and Burt, T. P.: The role of topography in controlling throughflow generation, Earth Surf. Process., 3, 331-344, 1978.

Bernier, P. Y.: Variable source areas and storm-flow generation: An update of the concept and a simulation effort, J. Hydrol., 79, 195213, 1985

Beven, K.: Hillslope hydrographs by the finite element method, Earth Surf. Process., 2, 13-28, 1977.

Beven, K. and Germann, P.: Macropores and water flow in soils revisited, Water Resour. Res., 49, 3071-3092, 2013.

Beven, K. and Kirkby, M. J.: A physically based, variable contributing area model of basin hydrology, Hydrolog. Sci. Bull., 24, 4369, 1979.

Brauer, C. C., Teuling, A. J., Overeem, A., van der Velde, Y., Hazenberg, P., Warmerdam, P. M. M., and Uijlenhoet, R.: Anatomy of extraordinary rainfall and flash flood in a Dutch lowland catchment, Hydrol. Earth Syst. Sci., 15, 1991-2005, doi:10.5194/hess15-1991-2011, 2011.

Burnash, R. J., Ferral, R. L., and McGuire, R. A.: A generalized streamflow simulation system: conceptual modeling for digital computers, US Department of Commerce National Weather Service and State of California Department of Water Resources, Sacramento, California, USA, 1973.

Buttle, J. M. and Sami, K.: Testing the groundwater ridging hypothesis of streamflow generation during snowmelt in a forested catchment, J. Hydrol., 135, 53-72, 1992.

Cloke, H. L., Anderson, M. G., McDonnell, J. J., and Renaud, J.P.: Using numerical modeling to evaluate the capillary fringe groundwater ridging hypothesis of streamflow generation, J. Hydrol., 316, 141-162, 2006.

Culligan, P. J., Barry, D. A., Parlange, J. Y., Steenhuis, T. S., and Haverkamp, R.: Infiltration with controlled air escape, Water Resour. Res., 36, 781-785, 2000.

Dixon, R. M. and Linden, D. R.: Soil air pressure and water infiltration under border irrigation, Soil Sci. Soc. Am. J., 36, 948-953, 1972.

Duan, Q., Schaake, J., and Koren, V.: A priori estimation of land surface model parameters, in: Land Surface Hydrology, Meteorology, and Climate: Observation and Modeling, Water Sci. and Appl. 3, edited by: Lakshmi, V., Albertson, J., and Schaake, J., AGU, Washington, D.C., 77-94, 2001.

Dunne, T.: Field studies of hillslope flow processes, in: Hillslope Hydrology, edited by: Kirkby, M. J. and Chorley, R. J., Wiley, Chichester, 227-293, 1978.

Dunne, T. and Black, R. D.: Partial area contributions to storm runoff in a small New England watershed, Water Resour. Res., 6, 1296-1311, 1970.

Dunne, T., Moore, T. R., and Taylor, C. H.: Recognition and prediction of runoff-producing zones in humid regions, Hydrolog. Sci. Bull., 20, 305-327, 1975.
Fiori, A., Romanelli, M., Cavalli, D. J., and Russo, D.: Numerical experiments of streamflow generation in steep catchments, J. Hydrol., 339, 183-192, 2007.

Freeze, R. A.: Role of subsurface flow in generating surface runoff: 2. Upstream source areas, Water Resour. Res., 8, 1272-1283, 1972.

Freeze, R. A.: Streamflow generation, Rev. Geophys., 12, 627-647, 1974.

Gillham, R. W.: The capillary fringe and its effect on water table response, J. Hydrol., 67, 307-324, 1984.

Hofer, M., Lehmann, P., Stähli, M., Seifert, S., and Krafczyk, M.: Two approaches to modeling the initiation and development of rills in a man-made catchment, Water Resour. Res., 48, W01531, doi:10.1029/2011WR010719, 2012.

Hopp, L., Harman, C., Desilets, S. L. E., Graham, C. B., McDonnell, J. J., and Troch, P. A.: Hillslope hydrology under glass: confronting fundamental questions of soil-water-biota coevolution at Biosphere 2, Hydrol. Earth Syst. Sci., 13, 21052118, doi:10.5194/hess-13-2105-2009, 2009.

Huxman, T., Troch, P. A., Chorover, J., Breshears, D. D., Saleska, S., Pelletier, J., and Zeng, X.: The Hills are Alive: Earth Science in a Controlled Environment, EOS Trans. AGU, 90, 120-120, doi:10.1029/2009EO140003, 2009.

Nguyen, H. T., Wiatr, T., Fernández-Steeger, T. M., Reicherter, K., Rodrigues, D. M. M., and Azzam, R.: Landslide hazard and cascading effects following the extreme rainfall event on Madeira Island (February 2010), Nat. Hazards, 65, 635-652, 2013.

Niu, G.-Y., Pasetto, D., Scudeler, C., Paniconi, C., Putti, M., Troch, P. A., DeLong, S. B., Dontsova, K., Pangle, L., Breshears, D. D., Chorover, J., Huxman, T. E., Pelletier, J., Saleska, S. R., and Zeng, X.: Incipient subsurface heterogeneity and its effect on overland flow generation - insight from a modeling study of the first experiment at the Biosphere 2 Landscape Evolution Observatory, Hydrol. Earth Syst. Sci., 18, 1873-1883, doi:10.5194/hess-18-1873-2014, 2014

Novakowski, K.-S. and Gillham, R. W.: Field investigations of the nature of water-table response to precipitation in shallow watertable environments, J. Hydrol., 97, 23-32, 1988.

O'Loughlin, E. M.: Saturation regions in catchments and their relations to soil and topographic properties, J. Hydrol., 53, 229-246, 1981.

Phi, S., Clarke, W., and Li, L.: Laboratory and numerical investigations of hillslope soil saturation development and runoff generation over rainfall events, J. Hydrol., 493, 1-15, 2013.

Robinson, J. S. and Sivapalan, M.: Instantaneous response functions of overland flow and subsurface stormflow for catchment models, Hydrol. Process., 10, 845-862, 1996.

Sklash, M. G. and Farvolden, R. N.: The role of groundwater in storm runoff, J. Hydrol, 43, 45-65, 1979.

Starr, J. L., DeRoo, H. C., Frink, C. R., and Parlange, J.-Y.: Leaching characteristics of a layered field soil, Soil Sci. Soc. Am. J., 42, 386-391, 1978.

Troch, P. A., Paniconi, C., and van Loon, E. E.: The hillslopestorage Boussinesq model for subsurface flow and variable source areas along complex hillslopes: 1. Formulation and characteristic response, Water Resour. Res., 39, 1316, doi:10.1029/2002WR001728, 2003. 
Turner, T. R., Duke, S. D., Fransen, B. R., Reiter, M. L., Kroll, A. J., Ward, J. W., Bach, J. L., Justice, T. E., and Bilby, R. E.: Landslide densities associated with rainfall, stand age, and topography on forested landscapes, southwestern Washington, USA, J. Hydrol., 259, 2233-2247, 2010.

van Esse, W. R., Perrin, C., Booij, M. J., Augustijn, D. C. M., Fenicia, F., Kavetski, D., and Lobligeois, F.: The influence of conceptual model structure on model performance: a comparative study for 237 French catchments, Hydrol. Earth Syst. Sci., 17, 42274239, doi:10.5194/hess-17-4227-2013, 2013.

Ward, R. C.: On the response to precipitation of headwater streams in humid areas, J. Hydrol., 74, 171-189, 1984.
Waswa, G. W., Clulow, A. D., Freese, C., Le Roux, P. A. L., and Lorentz, S. A.: Transient pressure waves in the vadose zone and the rapid water table response, Vadose Zone J., 12, doi:10.2136/vzj2012.0054, 2013.

Wilson, C. J., and Dietrich, W. E.: The contribution of bedrock groundwater flow to storm runoff and high pore pressure development in hollows, Erosion and Sedimentation in the Pacific Rim, Int. Assoc. Hydrol. Sciences Pub. No. 165, IAHS Press, Wallingford, UK, 49-59, 1987.

Zhao, R. J.: The Xinanjiang model applied to China, J. Hydrol., 135, 371-381, 1984. 